\title{
Analisis Pengaruh GCG dan Kinerja Keuangan Terhadap Pengungkapan Islamic Social Reporting (ISR)
}

\section{(Analysis of the GCG and Financial Performance Influences to Disclosure Islamic Social Reporting (ISR))}

\section{(An Empirical Study Among List of Jakarta Islamic Companies Period 2011-2015)}

\author{
Nindya Tyas Hasanah, Novi Wulandari Widiyanti*, Sudarno \\ Akuntansi, Fakultas Ekonomi dan Bisnis, Universitas Jember (UNEJ) \\ Jln. Kalimantan 37, Jember 68121 \\ E-mail:nindya.tyasha@gmail.com
}

\begin{abstract}
Abstrak
Penelitian ini bertujuan untuk menganalisa pengaruh good corporate governance dan kinerja keuangan terhadap pengungkapan Islamic Social Reporting (ISR). Islamic Social Reporting (ISR) merupakan indeks pengungkapan tanggung jawab sosial yang sesuai dengan prinsip syariah. Populasi dalam penelitian ini adalah perusahaan yang terdaftar di Jakarta Islamic Index selama periode tahun 2011-2015. Metode sampling yang digunakan dalam penelitian ini adalah purposive sampling. Total sampel yang digunakan dalam penelitian ini adalah sebanyak 55 perusahaan. Pengungkapan ISR dilakukan dengan cara analisis konten melalui metode skoring dari laporan tahunan perusahaan. Analisis data dilakukan dengan statistik deskriptif dan uji asumsi klasik serta pengujian hipotesis dengan metode regresi linier berganda, uji Adjusted $\mathrm{R}^{2}$, uji $\mathrm{F}$, dan uji t. Hasil dari penelitian ini menunjukkan bahwa ukuran komite audit, likuiditas dan profitabilitas berpengaruh signifikan terhadap pengungkapan ISR. Sedangkan ukuran dewan komisaris dan leverage tidak berpengaruh terhadap pengungkapan ISR.
\end{abstract}

Kata Kunci: Islamic Social Reporting (ISR), good corporate governance, kinerja keuangang, Jakarta Islamic Index

\begin{abstract}
This study aims to analyze of good corporate governance and financial performance influences to disclosure Islamic Social Reporting (ISR). Islamic Social Reporting (ISR) is a social responsibility disclosure index accordance to the sharia principles. Populations in this study are all companies that listed in Jakarta Islamic Index exchange in 2011-2015. The sampling method in this tudy is puposive sampling. The total number of samples in this study were 55 research samples. The disclosure of ISR is obtained by content analysis through scoring method from corporate annual reports. The analytical techniques was conducted by descriptif statistic and classical assumption test and also hypothesis was tested using multiple liniear regression method, Adjusted $\mathrm{R}^{2}$ test, $\mathrm{F}$ test and $\mathrm{t}$ test. The analysis showed that audit committee size, liquidity and profitability significantly affect the disclosure of ISR. Meanwhile, commissioners board size and leverage does not affect the disclosure of ISR.
\end{abstract}

Keywords: Islamic Social Reporting (ISR), good corporate governance, financial performance, Jakarta Islamic Index

\section{Pendahuluan}

Perkembangan dunia industri yang semakin modern saat ini menuntut perusahaan untuk terus berupaya mengelola sumber daya yang dimiliki secara optimal demi memenuhi kebutuhan masyarakat yang terus meningkat dari segi produksi dan konsumsi barang maupun jasa serta kebutuhan investasi. Pasar modal sebagai sarana investasi yang menjanjikan mulai menjadi pusat perhatian masyarakat Indonesia. Keberadaan pasar modal yang tangguh, berdaya saing global, dan terorganisir dengan baik juga turut membantu usaha pembangunan perekonomian nasional. Dalam rangka mendukung terwujudnya pasar modal selaku subsistem dari perekonomian nasional, kini industri pasar modal Indonesia mulai melirik pengembangan penerapan prinsip-prinsip syariah Islam untuk dijadikan alternatif instrumen investasi.

Indonesia dianggap sebagai salah satu negara dengan penganut agama Islam terbesar di dunia dan diharapkan menjadi suatu market yang sangat besar bagi pengembangan industri keuangan syariah. Perkembangan pasar modal syariah Indonesia dimulai ketika diterbitkannya reksadana syariah oleh PT Danareksa Investment pada tahun 1997.
Dalam rangka memandu investor yang ingin berinvestasi secara syariah, selanjutnya Bursa Efek Indonesia (BEI) meluncurkan Jakarta Islamic Index (JII) pada tahun 2000 dan menambah instrumen investasi syariah berupa obligasi syariah mudharabah serta sukuk korporasi pada tahun 2002. Infrastruktur pasar modal syariah terus diperkuat dengan penerbitan fatwa oleh Dewan Syariah Nasional (DSN), berbagai jenis produk syariah dari instrumen pasar modal yang dibuat oleh pelaku industri, dan pemberian kepastian hukum oleh BAPEPAM-LK. Hal ini menunjukkan trend positif pertumbuhan pasar modal syariah untuk menarik investor lebih banyak dan bersaing dengan industri keuangan syariah lainnya.

Kinerja saham syariah berperan penting bagi perkembangan pasar modal syariah di Indonesia. Pengkategorian saham syariah harus melalui screening dari Dewan Standar Nasional (DSN) Majelis Ulama Indonesia (MUI) dan Otoritas Jasa Keuangan (OJK). Kinerja saham syariah terus mengalami peningkatan dari tahun ke tahun. Hal tersebut dapat dilihat dari perkembangan kapitalisasi pasar dan indeks saham syariah di Jakarta Islamic Index (JII). Perkembangan indeks saham dan porsi kapitalisasi pasar di JII tersebut menjadi

* Corresponding author 
informasi penting bagi investor maupun pihak-pihak terkait lainnya pada entitas syariah.

Upaya perbaikan dan peningkatan aktivitas dalam memaksimalkan laba diperlukan perusahaan supaya memperoleh dukungan publik yang cukup besar atas kelangsungan usahanya. Peningkatan aktivitas tersebut dapat diwujudkan oleh pihak manajemen melalui pelaporan pertanggungjawaban sosial perusahaan baik secara internal maupun eksternal kepada stakeholders. Tanggung jawab sosial perusahaan atau Corporate Social Responsibility (CSR) dianggap sebagai inti dari etika bisnis perusahaan yang dapat digunakan sebagai sarana dalam mengomunikasikan perusahaan dengan stakeholders dimana legitimasi dapat diperbaiki dan keuntungan dapat diperoleh dari beberapa organisasi yang menggunakannya (Ahmad dan Sulaiman, 2004 dalam Nurkhin, 2010). Pemerintah Indonesia menjabarkan ketentuan terkait pengungkapan Corporate Social Responsibility (CSR) dalam Undang-Undang Nomor 40 Tahun 2007 tentang Perseroan Terbatas bahwa dalam laporan tahunan perusahaan harus memuat beberapa informasi, salah satunya adalah laporan pelaksanaan tanggung jawab sosial dan lingkungan.

Saat ini, konsep CSR mulai berkembang di bidang ekonomi yang berbasis syariah, tidak hanya di bidang ekonomi konvensional saja. CSR yang disesuaikan dengan nilai-nilai Islam ini dikenal dengan istilah Islamic Social Reporting (ISR). Pada tahun 2002, Prof.Roszaini Haniffa melalui jurnalnya yang berjudul Social Reporting Disclosure An Islamic Perspective mulai memperkenalkan tentang ISR, dimana prinsip dan konsep tentang ISR dijelaskan dalam lima tema pengungkapan. Selanjutnya pada tahun 2009, Othman et. al mengembangkan penelitian Haniffa dengan jurnal berjudul Determinants of Islamic Social Reporting Among Top Shariah-Approved Companies in Bursa Malaysia yang didalamnya terdapat satu tema tambahan dalam pengungkapan ISR yaitu tema tata kelola perusahaan.

Haniffa (2002) mengungkapkan bahwa pengukuran CSR dalam perspektif syariah masih mengacu kepada Global Reporting Initiative Index (Indeks GRI), dimana belum menggambarkan prinsip-prinsip syariah dalam Islam. Oleh karena itu, untuk mencapai tujuan akuntabilitas dan transparasi bagi entitas syariah dibutuhkan suatu kerangka pelaporan sosial yang sesuai dengan prinsip-prinsip syariah. Menanggapi kondisi tersebut, akhirnya AAOIFI (Accounting and Auditing Organization for Islamic Financial Institusions) membuat Indeks ISR sebagai tolak ukur pelaksanaan tanggung jawab sosial perbankan syariah, selanjutnya peneliti lainnya mengembangkan tentang item-item CSR yang seharusnya diungkapkan oleh entitas Islam (Othman et al., 2009).

Pengungkapan tanggung jawab sosial perusahaan sangat terkait dengan konsep Good Corporate Governance (GCG). Jika dikaitkan dengan pengungkapan tanggung jawab sosial, dewan komisaris dan komite audit mempunyai peran terhadap luasnya informasi yang akan disampaikan kepada publik. Jumlah anggota dewan komisaris yang semakin besar akan meningkatkan keefektivan dalam memonitoring manajemen, memudahkan upaya pengendalian terhadap $\mathrm{CEO}$, dan meningkatkan tekanan terhadap manajemen dalam memperluas informasi pengungkapan tanggung jawab sosial (Coller dan Gregory, 1999 dalam Sembiring, 2005). Peran komite audit dalam mengendalikan dan memantau manajamen puncak akan semakin efektif apabila ukuran komite audit semakin besar.

Berdasarkan teori agensi, para pemegang saham akan mendelegasikan wewenang yang mereka miliki kepada dewan komisaris untuk memonitor aktivitas manajemen perusahaan. Semakin besar ukuran dewan komisaris, maka upaya pengendalian CEO dan monitoring yang dilakukan perusahaan akan berjalan semakin efektif (Coller dan Gregory, 1999 dalam Sembiring, 2005). Monitoring yang baik diharapkan dapat memperluas pengungkapan Islamic Social Reporting (ISR) dalam memenuhi kebutuhan informasi stakeholders dan dapat meminimalisir informasi yang kemungkinan disembunyikan oleh manajemen perusahaan. Hasil penelitian Khoirudin (2013) menunjukkan bahwa ukuran dewan komisaris berpengaruh signifikan terhadap pengungkapan Islamic Social Reporting (ISR) perbankan syariah di Indonesia. Sejalan dengan Nurman dan Dewi (2013) yang membuktikan bahwa ukuran dewan komisaris berpengaruh signifikan terhadap tingkat pengungkapan Islamic Social Reporting. Berdasarkan hasil penelitian-penelitian tersebut mengindikasikan bahwa dewan komisaris memiliki peran yang penting karena bertugas mengawasi perusahaan dan menyampaikan semua informasi kepada stakeholders, termasuk informasi pengungkapan tanggung jawab sosial perusahaan.

Fatimah et al., (2016) melalui penelitiannya membuktikan bahwa komite audit memiliki pengaruh terhadap pengungkapan corporate social responsibility. Berdasarkan teori agensi, para prinsipal akan berusaha mencari informasi dan memberikan intensif untuk memastikan tanggung jawab agen terhadap kepemilikan perusahaan. Komite audit yang bertanggungjawab atas laporan keuangan, tata kelola perusahaan, dan pengawasan perusahaan diharapkan mampu memenuhi kebutuhan informasi prinsipal. Prinsipal akan mengukur tingkat hasil yang diperoleh dari usaha agen berdasarkan informasi yang diperolehnya. Biaya agensi yang dikeluarkan perusahaan dapat berkurang seiring dengan ketatnya pengawasan yang dilakukan oleh komite audit.

Teori legitimasi menyebabkan perusahaan berupaya meningkatkan kinerja keuangan demi mendapatkan sorotan publik. Kinerja keuangan yang ditunjukkan oleh kuatnya rasio likuiditas suatu perusahaan erat kaitannya dengan luasnya pengungkapan tanggung jawab sosial. Hasil penelitian Kariza (2014) menunjukkan bahwa likuiditas berpengaruh signifikan terhadap pengungkapan Islamic Social Reporting. Entitas syariah dengan kondisi keuangan yang kuat seharusnya cenderung mengungkapkan lebih banyak informasi terkait laporan pertanggungjawaban sosialnya secara syariah untuk menunjukkan kepada pihak eksternal bahwa suatu entitas syariah bersifat kredibel. Kebangkrutan usaha merupakan dampak ekstrim yang akan ditimbulkan apabila perusahaan sudah tidak mampu untuk memenuhi kewajiban keuangannya sampai tanggal ditetapkannya jatuh tempo. Perusahaan cenderung akan mengungkapkan informasi secara luas dalam laporan pertanggungjawaban sosialnya terkait kemampuan mereka untuk mempertahankan kelangsungan hidup usaha dan pemenuhan kewajiban keuangan sampai tanggal jatuh tempo.

Berdasarkan teori agensi diprediksi bahwa perusahaan yang memiliki rasio leverage tinggi cenderung mengungkapkan 
informasi yang lebih luas, karena perusahaan dengan struktur modal seperti itu menanggung biaya keagenan yang lebih tinggi (Jensen dan Meckling, 1976 dalam Indrayani, 2014). Transfer kemakmuran dari kreditur kepada manajer dan pemegang saham semakin tinggi seiring dengan semakin besarnya biaya agensi. Hasil penelitian Mahmud dan Irianto (2011) menunjukkan bahwa leverage perusahaan berpengaruh secara statistik signifikan terhadap luas pengungkapan laporan keuangan yang dilakukan oleh perusahaan. Pengungkapan yang lebih luas hendaknya dilaporkan oleh perusahaan yang mempunyai tingkat leverage tinggi. Hal itu dikarenakan pemberi hutang maupun pemegang saham membutuhkan informasi yang jelas mengenai kemampuan perusahaan dalam memenuhi kewajibannya dan dampak yang dapat ditimbulkan dari hutang jangka panjang terhadap pengungkapan tanggung jawab sosial perusahaan.

Kinerja ekonomi suatu perusahaan identik dengan profitabilitas, nilai perusahaan akan semakin meningkat seiring tingginya kinerja ekonomi perusahaan. Salah satu upaya untuk menarik minat investor adalah dengan menunjukkan nilai perusahaan yang tinggi. Semakin tinggi tingkat profitabilitas perusahaan maka semakin besar pengungkapan Islamic Social Reporting (ISR) yang dilakukan perusahaan. Sejalan dengan teori stakeholders yang menyatakan perusahaan bukanlah suatu entitas yang hanya beroperasi untuk kepentingan sendiri namun harus mampu memberikan manfaat bagi stakehodersnya. Hasil penelitian Nurkhin (2010) membuktikan bahwa profitabilitas berpengaruh terhadap pengungkapan tanggung jawab sosial perusahaan. Sejalan dengan hasil penelitian Othman et al (2009) dan Nurman dan Dewi (2013) yang membuktikan bahwa profitabilitas berpengaruh signifikan terhadap tingkat pengungkapan Islamic Social Reporting. Perusahaan yang semakin untung akan berusaha menarik perhatian investor dengan cara menunjukkan luasnya informasi yang diungkapkan dalam laporan pertanggungjawaban sosial.

Penelitian ini merupakan pengembangan dari penelitianpenelitian sebelumnya dengan menambah faktor lain berupa ukuran komite audit yang diperkirakan dapat mempengaruhi pengungkapan Islamic Social Reporting dan menguji ulang faktor ukuran dewan komisaris, likuiditas, leverage, serta profitabilitas. Tujuan dari penelitian ini adalah untuk menguji pengaruh ukuran dewan komisaris, ukuran komite audit, likuiditas, leverage, dan profitabilitas terhadap pengungkapan Islamic Social Reporting (ISR).

Penelitian ini menggunakan saham syariah yang terdaftar di Jakarta Islamic Index sebagai objek penelitian. Jakarta Islamic Index menggunakan 30 saham syariah paling likuid yang diperdagangkan dalam Bursa Efek Indonesia dan terdiri dari berbagai sektor industri sehingga analisis terhadap objek penelitian lebih akurat dengan waktu yang runtut. Periode yang digunakan dalam penelitian ini sebanyak 5 periode mulai tahun 2011-2015, dimana selama tahun tersebut indeks saham syariah dan kapitalisasi pasar saham syariah di Jakarta Islamic Index mengalami pertumbuhan yang signifikan dibandingkan dengan Indeks Harga Saham Gabungan yang terdapat di Bursa Efek Indonesia.

\section{Metode}

\section{Rancangan Penelitian}

Desain dalam penelitian ini adalah pengamatan. Data penelitian yang dibutuhkan adalah data sekunder yang berupa laporan tahunan dan laporan keuangan perusahaan. Data sekunder merupakan data penelitian yang diperoleh secara tidak langsung melali media perantara (diperoleh, dicatat, dan telah diolah oleh pihak lain). Data sekunder yang digunakan berupa bukti, catatan, atau laporan historis yang telah tersusun dalam arsip (data dokumenter).

\section{Jenis dan Sumber Data}

Jenis data yang digunakan dalam penelitian ini adalah data sekunder yaitu data yang diperoleh melalui kajian beberapa literatur yang berhubungan dengan permasalahan yang diangkat dan dari rujukan teoritis yang relevan (buku, buletin, jurnal, majalah, surat kabar serta internet). Sedangkan data yang digunakan dalam penelitian ini merupakan data sekunder berupa laporan tahunan (annual report) yang diterbitkan oleh perusahaan dan terdaftar di Jakarta Islamic Index (JII) periode 2011-2015. Laporan keuangan tahunan berasal berasal dari website Bursa Efek Indonesia (www.idx.co.id) dan website perusahaan yang menjadi sampel penelitian.

\section{Populasi dan Sampel Data}

Populasi yang digunakan dalam penelitian ini adalah entitas syariah dari berbagai sektor usaha yang terdaftar pada Jakarta Islamic Index (JII) tahun 2011-2015. Metode purposive sampling merupakan proses pemilihan sampel yang digunakan dalam penelitian ini. Purposive sampling merupakan teknik penentuan sampel menggunakan pertimbangan tertentu yang disesuaikan dengan kriteria yang ditetapkan oleh peneliti. Sampel dalam penelitian ini ditentukan dengan kriteria sebagai berikut.

1. Perusahaan yang tercatat dalam Jakarta Islamic Index (JII) tahun 2011-2015.

2. Perusahaan yang tidak pernah delisting dari Jakarta Islamic Index (JII) tahun 2011-2015.

3. Data-data tentang variabel penelitian yang diperlukan tersedia lengkap dalam laporan tahunan (annual report) yang diterbitkan.

4. Perusahaan yang menggunakan mata uang pelaporan Rupiah.

\section{Metode Analisa Data}

Analisa data yang digunakan dalam penelitian ini menggunakan aplikasi SPSS for windows versi 22. Dengan Uji Kualitas Data, Uji Asumsi Klasik, dan Uji Regresi.

\section{Hasil dan Pembahasan}

\section{Hasil Uji Asumsi Klasik}

Setelah dilakukan Uji Asumsi Klasik yang terdiri dari Uji Normalitas Data, Uji Multikolinieritas, Uji Heteroskedastisitas, dan Uji Autokorelasi dapat disimpulkan bahwa tidak ada masalah asumsi klasik pada penelitian ini.

\section{Hasil Pengujian Hipotesis}

\section{Analisis Regresi Linier Berganda}

Setelah melalui uji asumsi klasik, maka model regresi layak sebagai alat ukur untuk mendeteksi hubungan antar variabel yang diajukan, yaitu variabel independen Ukuran Dewan Komisaris (DK), Ukuran Komite Audit (KA), Likuiditas 
(CR), Leverage (DER), dan Profitabilitas (ROA). Rekapitulasi hasil Analisis Regresi adalah sebagai berikut.

Tabel 1. Hasil Analisis regresi Linier Berganda

\begin{tabular}{llll}
\hline Variabel & Koefisien & Sig & Keterangan \\
\hline Konstanta & 0,237 & 0,013 & - \\
DK & $-0,067$ & 0,587 & $\begin{array}{l}\text { Tidak } \\
\text { Signifikan }\end{array}$ \\
KA & 0,317 & 0,004 & Signifikan \\
CR & 0,306 & 0,011 & Signifikan \\
DER & $-0,098$ & 0,286 & Tidak \\
ROA & 0,536 & 0,000 & Signifikan \\
\hline
\end{tabular}

Sumber : Output SPSS 22, 2016

Berdasarkan output diatas diperoleh persamaan regresi dari pengujian tersebut adalah:

$\mathrm{Y}=0,237-0,067 \mathrm{KA}+0,317 \mathrm{DK}+0,306 \mathrm{CR}-0,098 \mathrm{DER}$ $+0,536 \mathrm{ROA}+\mathrm{e}$

\section{Uji Adjusted $\mathrm{R}^{2}$ (Koefisien Determinasi)}

Berdasarkan hasil Adjusted $\mathrm{R}^{2}$ terlihat bahwa nilai Adjusted $\mathrm{R}^{2}$ sebesar 0,583 atau 58,3\%. Hal ini menunjukkan bahwa $58,3 \%$ variabel Pengungkapan Islamic Social Reporting (ISR) dapat dijelaskan oleh Ukuran Dewan Komisaris, Ukuran Komite Audit, Likuiditas, Leverage, dan Profitabilitas, dan sisanya yaitu 41,7\% (100\% - 58,3\%) dijelaskan oleh variabel-variabel lain di luar persamaan.

Uji F

Dari hasil uji F diketahui konstanta dan signifikansi pengaruh variabel independen secara simultan atau bersama-sama terhadap variabel dependen. Nilai signifikansinya adalah sebesar 0,000, maka probabilitasnya jauh di bawah 0,05 . Berdasarkan hal ini dapat disimpulkan bahwa secara bersama-sama variabel independen dalam penelitian ini yaitu Ukuran Dewan Komisaris, Ukuran Komite Audit, Likuiditas, Leverage, dan Profitabilitas berpengaruh terhadap Pengungkapan Islamic Social Reporting (ISR) sebagai variabel dependen.

Uji t

Pengujian ini dilakukan untuk mengetahui pengaruh masingmasing variabel independen terhadap variabel dependen dengan membandingkan tabel dan thitung serta menggunakan tingkat signifikansi sebesar $0,05(\alpha=5 \%)$. Secara umum, ringkasan hasil pengujian hipotesis dengan Uji t dapat dilihat pada tabel berikut:

Tabel 2. Hasil Uji t

\begin{tabular}{lllll}
\hline Variabel & $\mathrm{t}_{\text {tabel }}$ & $\mathrm{t}_{\text {hitung }}$ & $\mathrm{Sig}$ & Keterangan \\
\hline $\mathrm{DK}$ & 2,004 & $-0,456$ & 0,587 & $\begin{array}{l}\text { Tidak } \\
\text { Signifikan }\end{array}$ \\
$\mathrm{KA}$ & 2,004 & 3,026 & 0,004 & Signifikan \\
$\mathrm{CR}$ & 2,004 & 2,626 & 0,011 & Signifikan
\end{tabular}

$\begin{array}{lllll}\text { DER } & 2,004 & -1,078 & 0,286 & \begin{array}{l}\text { Tidak } \\ \text { Signifikan }\end{array} \\ \text { ROA } & 2,004 & 4,217 & 0,000 & \text { Signifikan }\end{array}$

Sumber : Output SPSS 22, 2016

\section{Pembahasan}

\section{Pengaruh Ukuran Dewan Komisaris terhadap Pengungkapan Islamic Social Reporting (ISR)}

Hasil penelitian menunjukkan bahwa ukuran dewan komisaris tidak berpengaruh terhadap pengungkpan Islamic Social Reporting (ISR). Hal ini dapat ditunjukkan dengan nilai signifikansi sebesar 0,587 yang berada di atas 0,05 $(0,587>0,05)$. Tidak adanya pengaruh tersebut dapat terjadi karena dewan komisaris tidak mempunyai pengaruh secara langsung terhadap urusan pengoperasian perusahaan dan pelaksanaan tata kelola perusahaan. Informasi yang tidak menguntungkan cenderung tidak dilaporkan oleh perusahaan, karena dianggap sebagai bad news bagi publik yang akan mempengaruhi keputusan mereka dalam berinvestasi. Hasil penelitian ini tidak berhasil mendukung teori agensi dan pendapat dari Coller dan Gregory (1999) dalam Sembiring (2005) yang menyatakan bahwa semakin banyak jumlah dewan komisaris maka upaya pengendalian CEO dan monitoring yang dilakukan perusahaan akan berjalan semakin efektif.

Hasil penelitian ini sejalan dengan penelitian yang dilakukan oleh Nur Anisa Dipika (2014), Mariska Nanda Savira (2015), Miftachul Hidayati (2015), dan Awalya dan Asrori (2016) yang membuktikan bahwa ukuran dewan komisaris tidak berpengaruh terhadap pengungkapan Islamic Social Reporting (ISR). Namun berbeda dengan penelitian yang dilakukan oleh Rifki Nurman dan Miranti Kartika Dewi (2013) serta Amirul Khoirudin (2013) yang menyatakan bahwa ukuran dewan komisaris berpengaruh positif dan signifikan terhadap pengungkapan Islamic Social Reporting (ISR).

\section{Pengaruh Ukuran Komite Audit terhadap Pengungkapan Islamic Social Reporting (ISR)}

Hasil penelitian menunjukkan bahwa ukuran komite audit berpengaruh terhadap pengungkpan Islamic Social Reporting (ISR). Hal ini dapat ditunjukkan dengan nilai signifikansi sebesar 0,004 yang berada di bawah 0,05 $(0,004<0,05)$. Semakin banyak jumlah komite audit yang dimiliki oleh perusahaan maka pihak manajemen perusahaan akan memiliki tekanan yang lebih tinggi untuk mengungkapan Islamic Social Reporting di dalam laporan tahunan perusahaan. Komite audit dijadikan sebagai salah satu pendorong pada mekanisme corporate governance yang dapat mempengaruhi pengungkapan tanggung jawab sosial perusahaan. Berdasarkan teori agensi, para prinsipal akan berusaha mencari informasi dan memberikan intensif untuk memastikan tanggung jawab agen terhadap kepemilikan perusahaan. Komite audit yang bertanggungjawab atas laporan keuangan, tata kelola perusahaan, dan pengawasan perusahaan diharapkan mampu memenuhi kebutuhan informasi prinsipal tersebut.

Hasil penelitian ini sejalan dengan penelitian yang dilakukan oleh Fatimah et al (2016) yang membuktikan bahwa komite audit berpengaruh positif terhadap Corporate Social 
Responsibility (CSR). Penelitian ini juga mendukung hasil penelitian Lutfan Dwi Asyhari (2016) yang membuktikan bahwa ukuran komite audit berpengaruh positif dan signifikan terhadap pengungkapan Islamic Social Reporting (ISR). Namun berbeda dengan penelitian yang dilakukan oleh Ratnasari (2011) yang menyatakan bahwa ukuran komite audit tidak berpengaruh secara signifikan terhadap luas pengungkapan sustainability report.

\section{Pengaruh Likuiditas terhadap Pengungkapan Islamic Social Reporting (ISR)}

Hasil penelitian menunjukkan bahwa likuiditas berpengaruh terhadap pengungkpan Islamic Social Reporting (ISR). Hal ini dapat ditunjukkan dengan nilai signifikansi sebesar 0,011 yang berada di bawah $0,05(0,011<0,05)$. Semakin tinggi tingkat likuiditas yang dimiliki oleh perusahaan maka perusahaan memiliki dorongan yang tinggi untuk memperluas pengungkapan Islamic Social Reporting. Likuiditas menjadi salah satu faktor penting dalam pelaksanaan evaluasi perusahaan oleh pihak yang berkepentingan seperti kreditur, investor, dan pemerintah setempat (Naser 1994 dalam Dewi, 2012). Teori legitimasi menyebabkan perusahaan berupaya meningkatkan kinerja keuangan demi mendapatkan sorotan publik. Kinerja keuangan yang ditunjukkan oleh kuatnya rasio likuiditas suatu perusahaan erat kaitannya dengan luasnya pengungkapan tanggung jawab sosial. Perusahaan dengan tingkat likuiditas yang tinggi akan memberikan sinyal kepada perusahaan yang lain untuk menunjukkan bahwa suatu perusahaan lebih baik dari perusahaan lainnya. Sinyal tersebut diberikan oleh perusahaan dengan cara mengungkapkan informasi yang cukup luas melalui laporan pertanggungjawaban sosialnya.

Hasil penelitian ini sejalan dengan penelitian yang dilakukan oleh Ayu Kariza (2014) yang membuktikan bahwa likuiditas memiliki pengaruh signifikan terhadap pengungkapan Islamic Social Reporting (ISR). Namun berbeda dengan penelitian yang dilakukan oleh Indah Fitri Karunia Dewi (2012) yang menyatakan bahwa likuiditas tidak berpengaruh secara signifikan terhadap pengungkapan Islamic Social Reporting.

\section{Pengaruh Leverage terhadap Pengungkapan Islamic Social Reporting (ISR)}

Hasil penelitian menunjukkan bahwa leverage tidak berpengaruh terhadap pengungkpan Islamic Social Reporting (ISR). Hal ini dapat ditunjukkan dengan nilai signifikansi sebesar 0,286 yang berada di atas $0,05(0,286>0,05)$. Tidak adanya pengaruh tersebut dapat terjadi karena kreditur memiliki kemampuan dalam memperoleh informasi dan pengungkapan lainnya yang bukan hanya bersumber dari laporan tahunan perusahaan. Informasi dan pengungkapan lainnya dapat diperoleh kreditur melalui laporan interim yang disediakan oleh perusahaan, perjanjian (devt covenant) maupun tanya jawab secara langsung dengan pihak manajemen perusahaan (Dewi, 2012). Kreditur tidak terlalu menuntut perusahaan untuk melakukan pengungkapan Islamic Social Reporting secara luas karena masih bergantungnya kreditur pada sumber informasi selain laporan tahunan perusahaan. Semakin tingginya leverage suatu perusahaan, besar kemungkinan perusahaan tersebut akan melanggar kontrak hutangnya dengan cara melaporkan laba di masa sekarang lebih tinggi dibandingkan dengan laba pada periode selanjutnya. Tingginya laba yang dilaporkan tersebut menyebabkan manajer harus mengurangi biaya-biaya yang ada, diantaranya biaya terkait pengungkapan tanggung jawab sosial perusahaan.

Hasil penelitian ini sejalan dengan penelitian yang dilakukan oleh Ayu Kariza (2014) dan Miftachul Hidayati (2015) yang membuktikan bahwa leverage tidak memiliki pengaruh yang signifikan terhadap pengungkapan Islamic Social Reporting (ISR). Namun berbeda dengan penelitian yang dilakukan oleh Ali Rama dan Meliawati (2014) yang menyatakan bahwa leverage berpengaruh positif dan tidak signifikan terhadap pengungkapan ISR.

\section{Pengaruh Profitabilitas terhadap Pengungkapan Islamic Social Reporting (ISR)}

Hasil penelitian menunjukkan bahwa profitabilitas berpengaruh terhadap pengungkpan Islamic Social Reporting (ISR). Hal ini dapat ditunjukkan dengan nilai signifikansi sebesar 0,000 yang berada di bawah 0,05 $(0,000<0,05)$. Hubungan positif antara profitabilitas dan pengungkapan sosial yang lebih luas dapat dilihat dari semakin banyaknya keuntungan yang diperoleh suatu perusahaan (Haniffa dan Cooke, 2005). Profitabilitas yang tinggi menggambarkan bahwa perusahaan dapat menanggung biaya yang lebih tinggi untuk mengungkapkan informasi yang luas pada laporan pertanggungjawaban sosial. Profitabilitas identik dengan kinerja ekonomi di suatu perusahaan, dimana perusahaan yang mempunyai profitabilitas tinggi cenderung untuk mengungkapkan pertanggungjawaban sosial secara luas dengan tujuan menarik minat investor untuk menanamkan dananya. Perusahaan terdorong untuk mengungkapkan informasi yang lebih rinci dalam laporan tahunan mereka dalam rangka mengurangi biaya politik dan menunjukkan kinerja keuangan perusahaan kepada publik apabila perusahaan memiliki profit yang tinggi sehingga mempunyai kekuasaan penuh untuk menerapkan suatu kebijakan.

Hasil penelitian ini sejalan dengan penelitian yang dilakukan oleh Othman et al. (2009), Indah Fitri Karunia Dewi (2012), Rifki Nurman dan Miranti Kartika Dewi (2013), dan Nur Anisa Dipika (2014) yang membuktikan profitabilitas berpengaruh positif dan signifikan terhadap pengungkapan Islamic Social Reporting (ISR). Namun berbeda dengan penelitian yang dilakukan oleh Ayu Kariza (2014) dan Tria Karina Putri dan Etna Nur Afri Yuyetta (2014) yang menyatakan profitabilitas tidak berpengaruh terhadap pengungkapan ISR.

\section{Simpulan}

Berdasarkan hasil pengujian terhadap hipotesis dan analisis data yang telah diuraikan sebelumnya, maka dapat disimpulkan bahwa variabel ukuran komite audit, likuiditas, dan profitabilitas berpengaruh signifikan terhadap pengungkapan Islamic Social Reporting (ISR). Sedangkan variabel ukuran dewan komisaris, dan leverage tidak berpengaruh terhadap pengungkapan Islamic Social Reporting (ISR).

\section{Referensi}

Asyhari, Lutfan Dwi. 2016. Pengaruh Corporate Governance Terhadap Pengungkapan Islamic Social Reporting Pada Bank Umum Syariah di Indonesia. Jurnal Universitas Muhammadiyah Yogyakarta.Pg. 15. 
Dewi, Indah Fitri Karunia. 2012. Analisis Pengaruh Profitabilitas, Leverage, Likuiditas, Ukuran Perusahaan, dan Porsi Kepemilikan Publik atas Saham Terhadap Pengungkapan Islamic Social Reporting pada Perusahaan Jakarta Islamic Index. Skripsi Universitas Indonesia.

Dipika, Nur Anisa. 2014. Pengaruh Good Corporate Governance, Ukuran Perushaan dan Profitabilitas terhadap Pengungkapan Islamic Social Reporting. Skripsi Universitas Islam Negeri Sunan Kalijaga.

Fatimah, Siti., Makhdalena dan Trisnawati, Fenny. 2016. Pengaruh Komisaris Independen dan Komite Audit Terhadap Pengungkapan Corporate Social responsibility Perusahaan Pertambangan di Bursa Efek Indonesia Periode 2012 s.d 2014. Jurnal Universitas Riau.Pg. 8-9.

Haniffa, R. 2002. Social Reporting Disclosure: An Islamic Perspective. Indonesian Management \& Accounting Research. Vol. 1 (2): 128-146.

Haniffa, R. M., \& Cooke, T. E. 2005. The Impact of Culture and Governance on Corporate Social Reporting. Journal of Accounting and Public Policy 24: 391-430.

Hidayati, Miftachul. 2015. Pengaruh Karakteristik Perusahaan Terhadap Pengungkapan Islamic Social Reporting (ISR) Pada Perbankan Syariah Yang Terdaftar di OJK. Jurnal Universitas Islam Negeri (UIN) Maulana Malik Ibrahim.Pg. 8.

Jannah, Awalya Ma'rifatul dan Asrori. 2016. Pengaruh GCG, Size, Jenis Produk dan Kepemilikan Saham Publik. Accounting Analysis Journal. ISSN 2252-6765. Vol. 5 (1): 1-9.

Kariza, Ayu. 2014. Faktor-Faktor yang Mempengaruhi Pengungkapan Islamic Social Reporting Pada Perusahaan yang Listing di Jakarta Islamic Index. Jurnal Akuntansi. Pg. 10-11.

Khoirudin, Amirul. 2013. Pengaruh Elemen Good Corporate Governance terhadap Pengungkapan Islamic Social Reporting pada Perbankan Syariah di Indonesia. Skripsi Universitas Negeri Semarang.

Nurkhin, Akhmad. 2010. Corporate Governance dan Profitabilitas; Pengaruhnya terhadap Pengungkapan Tanggung Jawab Sosial Perusahan
(Studi Empiris pada Perusahaan yang Terdaftar di Bursa Efek Indonesia). Jurnal Magister Akuntansi. Vol. 2 (1): 46-55.

Nurman, Rifki dan Dewi, Miranti Kartika. 2013. Faktor yang Mempengaruhi Tingkat Pengungkapan Islamic Social Reporting (ISR) Pada Perusahaan yang Terdaftar dalam Indonesia Sharia Stock Index (ISSI). Jurnal Universitas Indonesia.Pg. 14-16.

Othman, R., Thani, A. M., \& Ghani, E. K. 2009. Determinants of islamic Social Reporting Among Top Shariah-Approved Companies in Bursa Malaysia. Resarch Journal of International Studies. Issue 12: 4-20.

Putri, Tria Karina dan Yuyetta, Etna Nur Afri. 2014. Faktor-Faktor Yang Mempengaruhi Islamic Social Reporting Perusahaan-Perusahaan Yang Terdaftar Pada Indeks Saham Syariah Indonesia (ISSI) Tahun 20112012. Diponegoro journal of accounting. ISSN (Online): 2337-3806. Vol.3 (2): 1-9.

Rama, Ali dan Meliawati. 2014. Analisis determinan Pengungkapan Islamic Social Reporting: Studi Kasus Bank Umum Syariah di Indonesia. Jurnal Ekonomi Syariah. Vol.2 (1): 95-115.

Ratnasari, Yunita. 2011. Pengaruh Corporate Governance Terhadap Luas Pengungkapan Tanggung Jawab Sosial Perusahaan di dalam Sustainability Report. Jurnal Univeristas Diponegoro.Pg. 20-23.

Savira, Mariska Nanda. 2015. Pengaruh Ukuran Perusahaan, Ukuran Dewan Komisaris, Ukuran Dewan Pengawas Syariah, Cross-Directorship, Kepemilikan Manajerial Dan Kepemilikan Institusional Terhadap Pengungkapan Islamic Social Reporting (ISR). Skripsi Universitas Negeri Semarang.

Sembiring, Eddi Rismanda. 2005. Karakteristik Perusahaan dan Pengungkapan Tanggung Jawab Sosial: Study Empiris Pada Perusahaan yang Tercatat di Bursa Efek Jakarta. SNA VIII, Solo. Sumatera Utara: Universitas Katolik St. Thomas.Pg. 387-388.

Indrayani, Vera. 2014. Pengaruh Profitabilitas, Leverage dan Likuiditas Terhadap Kelengkapan Pengungkapan Sukarela dalam Laporan Tahunan Pada Perusahaan Manufaktur yang Terdaftar di BEI Pada Tahun 20102012. Skripsi Universitas Diponegoro. 